\title{
"Outsiders at the Table"-Diversity Lessons from the Biology Scholars Program at the University of California, Berkeley
}

\section{John T. Matsui*}

Biology Scholars Program, University of California, Berkeley, Berkeley, CA 94720

\section{INTRODUCTION}

In 2017, at two campus-wide events to discuss diversity efforts in science, two senior scientists, both of whom were white men from separate institutions, declared, "We know what to do to fix underrepresentation in STEM, all we need is to do it." I found what they said to be profoundly ironic. Their independent, nearly identical declarations captured the essence of why I think that, after 40 years of efforts to diversify science, technology, engineering, and mathematics (STEM), underrepresentation persists. Their words reminded me of when the special diversity edition of the journal Science was published in 1992, the same year that I cofounded the Biology Scholars Program (BSP), an undergraduate diversity program at the University of California, Berkeley (UC Berkeley), that to this day I direct. In the editorial "Minorities in Science-The Pipeline Problem" (1992), the editor stated, with great certainty, "The low percentages of minorities in science reflect ... that prejudice did exist," and "The world fortunately has changed," and "Under these circumstances the opportunities for able young minority scientists or women should be good in future years."

From 1992 to the present, 3500 UC Berkeley undergraduates have participated in the BSP, of whom $80 \%$ were first-to-college/low-income students, $70 \%$ were women, and $60 \%$ were from ethnic groups (African American, Hispanic, and Native American) underrepresented in STEM. BSP's focus has been to develop "undervalued talent," like the Oakland Athletics (Lewis, 2004), by working with students who enter Berkeley and are considered less well prepared to succeed in STEM majors based on their lower Scholastic Aptitude Test (SAT) scores and high school grade point averages (GPAs). We have found repeatedly that, despite these so-called "deficits," BSP members finished in equal percentages with biology degrees and with nearly the same exit GPAs compared with traditional students in their cohorts (Matsui et al., 2003). In a more recent analysis of intended biology majors entering in 2002-2008 as first-year students and graduating in four or five years, two things remain consistent with our earlier study:

- Women, underrepresented ethnic minorities (URMs), and first-to-college intended majors with lower scores and GPAs continue to be overrepresented in BSP (Figure 1). Moreover, $52 \%$ of our members come from the bottom half of California high schools as formerly ranked by the Academic Performance Index score assigned to each school by the California Department of Education as a measure of its academic performance level (www.cde.ca.gov/ta/ac/ap).

- URM members of the BSP community continue to graduate with biology degrees in nearly equal percentages as biology majors at large and earn high GPAs (3.0 or higher) in percentages only 12 points lower than biology majors at large (vs. 30 points lower for URMs not in BSP; Figure 2).

These results demonstrate that, in the right environment, students from backgrounds that least fit the profile of historically successful students in biology at Berkeley can attain parity in academic performance with peers from more resource-rich

Kenneth Gibbs, Monitoring Editor

Submitted Dec 26, 2017; Revised Jun 7, 2018; Accepted Jun 12, 2018

CBE Life Sci Educ September 1, 2018 17:es11 DOI:10.1187/cbe.17-12-0276

*Address correspondence to: John T. Matsui (matsuiaberkeley.edu).

(c) 2018 Matsui CBE-Life Sciences Education ( 2018 The American Society for Cell Biology. This article is distributed by The American Society for Cell Biology under license from the author(s). It is available to the public under an AttributionNoncommercial-Share Alike 3.0 Unported Creative Commons License (http:// creativecommons.org/licenses/by-nc-sa/3.0). "ASCB®" and "The American Society for Cell Biology ${ }^{\circledR}$ " are registered trademarks of The American Society for Cell Biology. 


\section{BSP Demographics}

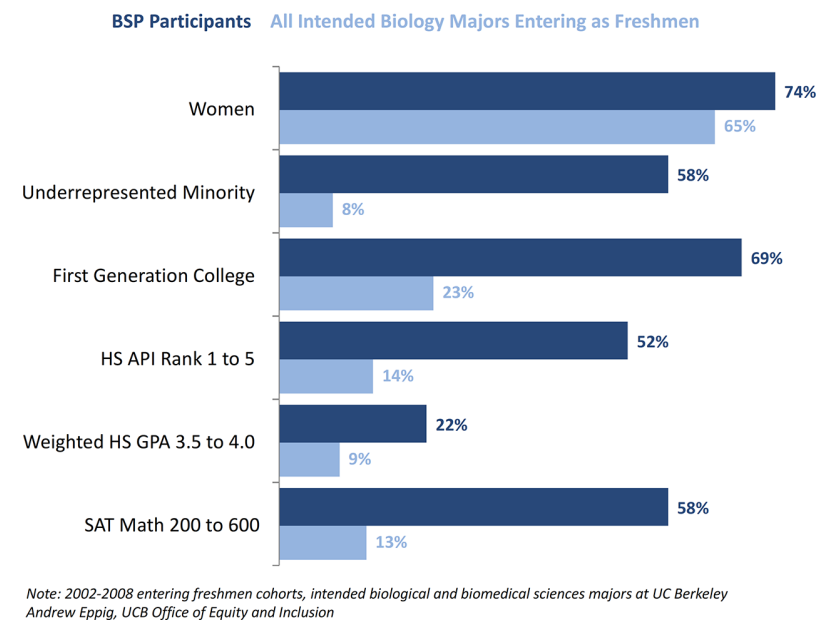

FIGURE 1. BSP participants vs. all intended biology majors entering as freshmen at UC Berkeley (2002-2008).

backgrounds. I too come from a first-to-college, low-income background, and have always felt myself to be an "outsider" in academia. Over the past 26 years, I have chosen to support these other "outsiders." I offer here several questions, recommendations, and challenges that I have distilled from 26 years of work with BSP that may help the STEM community move the needle to diversify who participates and succeeds in our disciplines.

\section{HAS OUR WORLD REALLY CHANGED?}

Consider these quotes, statements recently made by STEM faculty and staff to my students and to me.

- Teaching: "I teach science, not students." During a faculty pedagogy workshop, a STEM colleague stated this in response to the question of how to teach to the new student demographic.

- Advising: "You may like science, but science does not like you." A departmental advisor said this to one of my students upon reviewing her transcript and seeing that she received a "C" in both first-semester general chemistry and organic chemistry. What the advisor did not know was that the last time my student took chemistry was in the 10th grade and that it was poorly taught, with her high school teacher reading out of the text. Further, my student earned her " $\mathrm{C}$ " in the highly competitive, curve-graded course without a textbook until the sixth week of the semester because her financial aid was late and she was working 15 hours a week as a work-study student.

- Research mentoring: "This is science, leave your culture at the door." The principal investigator (PI) of a lab said this to one of my African-American male students on the first day the student joined his lab group. Is science really "culture blind," as this PI contends? Would the PI have said this to a white or Asian student on the first day?

- The solution: "If we'd only admit the right students, there'd be no problem." This was my colleague's response as we discussed underrepresentation in STEM.

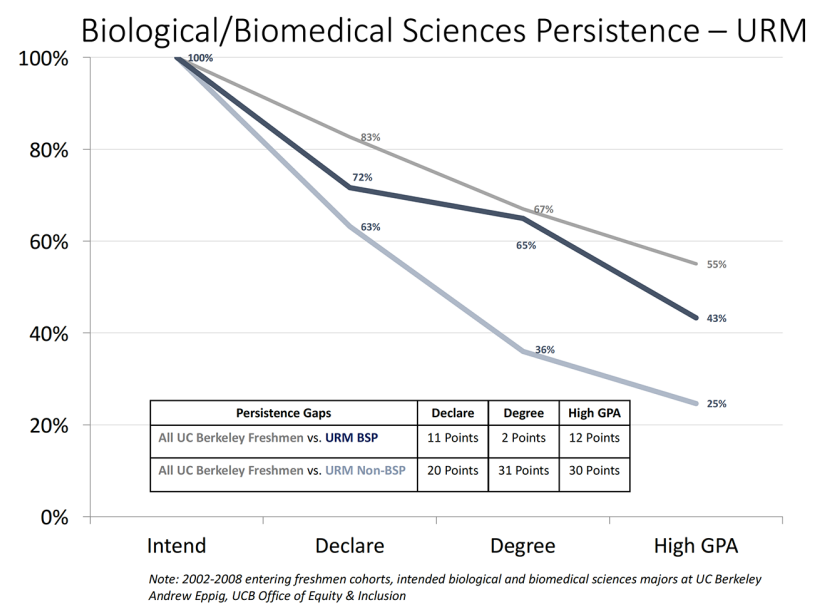

FIGURE 2. Persistence at UC Berkeley of URM students entering as freshmen (2002-2008) in biological/biomedical sciences majors.

What is the cumulative effect on students of experiencing a climate shaped by this type of thinking? While we are continuing to tease apart BSP's impact on our students' science efficacy (students' belief that they can do science), alignment of their science and personal identities, adoption of the values of the science community, and susceptibility to stereotype threat, our working hypothesis is that BSP "works" by reducing "institutional ambiguity" (Estrada et al., 2018). This ambiguity is the result of the mixed messages the students receive about diversity's value at Berkeley. Public macroaffirmations combined with individual microaggressions lead to conflict about belonging in STEM and students' ability to do STEM. For example, Berkeley publicizes excellence and diversity as mutually desirable and attainable institutional goals (macroaffirmations). However, in the day-to-day individual interactions (e.g., being passed over for others assumed more academically capable when students choose lab partners; the surprise when peers learn that you are a STEM major), students may experience contradictory messages (microaggressions) that they do not belong and/or are not capable (e.g., the four examples given earlier).

\section{WHAT IS "TALENT"?}

BSP data suggest that we need to rethink how we think about "talent" for STEM and how we assess who is "qualified." BSP members' success over the past 26 years is evidence that so-called less qualified students can succeed in STEM at UC Berkeley in a proper academic environment. Two interrelated ideas are central to selecting BSP members (Craig, 2015):

- Starting point, which is where students start in life in terms of their available resources, opportunities, and challenges

- Distance traveled, which is what they did to leverage their good fortune and overcome their hurdles

Rather than SAT scores and GPAs, we assess alternative predictors of success, such as resilience, persistence, willingness to give and seek help, a passion for science, and a love for 
taking on challenges. We look for these qualities in the essays that applicants write and in subsequent in-person interviews. Further, we recognize that our selection criteria of resilience and persistence may be considered controversial within the current debate about the use of "grit" as a predictor of success (e.g., Duckworth et al., 2007; Schreiner, 2017; Willingham, 2016) and is one focus of our future research on "why BSP works."

\section{HOW SHOULD WE INVEST IN DIVERSITY?}

We all have limited resources to support the development of STEM talent. Should we invest in a few students, in effect "skimming the cream?" Or should we invest in the many by cultivating their talent? The belief in an objective meritocracy dominates the thinking in STEM (McCoy and Major, 2007). In spite of the climate of hope and aspirations for success that meritocracy creates, Kwate and Meyer (2010) point out that "opportunities are not equally distributed, and they are not allotted solely by meritocratic criteria" (p. 1831). Further, they go on to say that the "meritocratic ideology can obfuscate features of the opportunity structure that erect barriers to success" (p. 1832).

STEM culture relies heavily on the quantitative assessment of talent (e.g., GPA, standardized test rankings) and the value of competition and curve grading to sort talent (e.g., Seymour and Hewitt, 1997). These practices are grounded in the ideology of a meritocracy in which individuals "deserve what they get and get what they deserve." The well-intentioned programs that use this lens to select and support whom they perceive to be the most STEM qualified reinforce the myth of meritocracy. BSP operates on the premise that our limited resources should be used to identify and address the structural failings of our institutions rather than rationalizing success in STEM as the natural outcome of individual differences in skill, talent, or perceived work ethic. We must democratize our institutions such that they provide access to all with an interest in STEM. The Americans with Disabilities Act $(1990,2008)$ provides a framework convergent with the Inclusive Excellence framework (Association of American Colleges and Universities [AAC\&U], 2017; Howard Hughes Medical Institute [HHMI], 2017) and systemic change recommendations (Coalition for Reform of Undergraduate STEM Education, 2014) that support this recommendation.

\section{LOOKING FORWARD-RECOMMENDATIONS}

Where are we and where do we want to be in our work to diversify STEM? In his commentary, Nivet (2011) uses a diversity framework previously implemented at IBM to identify three phases in the evolution of diversity thinking in the academic medical community:

- Diversity 1.0: At this level, excellence and diversity are viewed as competing ends.

- Diversity 2.0: At this level, diversity and excellence coexist, with diversity on the periphery.

- Diversity 3.0: At this level, diversity and inclusion are woven into the core workings of the institution and are considered integral for achieving excellence.

To address the causes of underrepresentation, the STEM community must evolve from our current Diversity 1.0 and 2.0 thinking, practices, and policies to a Diversity 3.0 plane. I offer two recommendations on the premise that substantial research already exists to provide us with the theory and evidence to accomplish this (Valantine and Collins, 2015).

\section{Recommendation 1: Fix Our Institutions, Not Our Students} We must shift the locus of responsibility for underrepresentation onto our institutions, changing the way schools do business versus "fixing the student." This means improving the structure of the curriculum and its delivery; reformulating school policies and procedures; training faculty (Brownwell and Tanner, 2012; Connolly and Millar, 2006; Cox, 2004; Handelsman et al., 2004); and improving the classroom, campus, and research lab climate and culture (AAC\&U, 2017; HHMI, 2017). To do this, all of us, faculty, administrators, and staff alike, must hold ourselves and our institutions accountable. Data disaggregated by student background (e.g., ethnicity, gender, socioeconomic status), including time to degree, existing intervention programs, and student participation in research training, are needed to shift our thinking from numbers of students and programs as end goals to what we can do to make our institutions more inclusive. In support of this, funding agencies should require STEM degree attrition and attainment data from institutions that receive support in a standardized format that identifies disparity and equity (Estrada et al., 2016).

We must reconceptualize our practices and policies in terms of how they affect our students' perceptions and experiences of kindness, dignity, and belonging. But we also need to be mindful not to frame or to message what we do as "charity" or "remedial," a frame that feeds into the deficit view of students from underrepresented backgrounds. Rather, we need to ensure that the reality and message we convey acknowledge the value of students from all backgrounds in the academy. To demonstrate this, we must structure regular opportunities for students to connect their backgrounds, interests, values, and so on to what they are learning. For example, we need to connect course work to students' values to increase persistence and maximize cognitive gains (Harackiewicz et al., 2016). Further, we need to promote teaching innovations that engage students to minimize widespread perception among freshmen that the science environment is impersonal and competitive (Hurtado et al., 2011).

\section{Recommendation 2: Work from Our Students Outward}

Our work should be driven by considerations of the fit between our practices and our students, both culturally and resourcewise. For example, our students' cultural values influence their science experience and career interests (Jackson et al., 2016). There is emerging research about the distinct values that motivate many URM scientists to pursue science careers and the importance of congruence of personal values and career opportunities to fulfill those values for scientists from all backgrounds (Gibbs and Griffin, 2013; Byars-Winston, 2014). For example, URM students in STEM more highly endorse communal goals, and URMs and women are more likely to engage in science for altruistic reasons in pursuit of valued social causes (Estrada et al., 2016; Harackiewicz et al., 2016), and this influence is not equal across ethnic groups (Thoman et al., 2014). Students from cultural backgrounds that place high value on helping others through work can be retained in science when their research experience embraces this cultural strength. We 
must also address resource disparities among students. Financial need and the need to work negatively impact student performance (Tinto, 2006). Students from low-income backgrounds face the dilemma of working to "pay the bills" versus committing their time to unpaid science-related opportunities such as research. Regular paid opportunities to "do science" must be available to provide equitable access to STEM. In short, we must recognize that none of us ends up in a career by chance. The extent to which we all are attracted to and successful in particular education and career paths is influenced by more than just our ability.

Institutional change is incremental-some would say it operates on a "geologic scale." To address underrepresentation in STEM, we should keep in mind that the lack of diversity is less a numerical issue than it is a structural issue (Gibbs et al., 2016). Diversity efforts that focus on selecting only the "best" students, with high test scores and GPAs, should be called out for what they are, "shortcuts" that work around the real underlying institutional inequities (practices, policies, and beliefs) that result in chronic underrepresentation.

Acknowledging that the work of democratizing our institutions is hard, messy, and "evolutionary" rather than "revolutionary," what do we do? As we struggle toward parity in our STEM disciplines, the community needs to take a "both ... and" approach-working to change our institutions, while simultaneously helping today's students from underrepresented backgrounds navigate institutional policies and practices that are poorly designed to support them. We need programs that target talented students whose potential would otherwise be underexpressed, and at the same time, we must work to make our institutions more equitable for all. Moreover, these programs, rather than being viewed as "solutions" unto themselves, should be viewed as pilot "experiments" or "incubators" that help our institutions develop scalable interventions that mitigate the negative effects of institutional biases and barriers to the success of underrepresented students in STEM. Finally, we need to reconceptualize programs as short-term "workarounds" versus permanent fixes for what is wrong with our institutions.

In the end, what will success look like? Success would mean that we will no longer need programs for "special populations." Instead diversity and inclusion will be a by-product of highly functioning colleges and universities that focus on each student's intellectual and social development (Craig, 2015; Kulkarni and Rothwell, 2015). The expectation will be that each student will have an equal opportunity to excel academically with the support of all campus members. All of this will be fostered by institutional policies and practices responsive to the diverse backgrounds of its learners within a culture of kindness, dignity, and belonging.

To this, some would counter that there is such a thing as innate individual ability. Using the athlete analogy, some would resort to explaining success in STEM based on variation in aptitude, that is, individual genetic or biological differences. Before absolving ourselves of responsibility for things over which we have no control, we should do everything possible to design an educational system in which there is equal opportunity. The 26 years of BSP student success provides insights into what an equitable institution might look like. If the program was adopted at scale, our colleges and universities could more fully cultivate and benefit from the STEM talent of individuals from all backgrounds and not just those who fit the traditional, status quo profile of success.

\section{REFERENCES}

Americans with Disabilities Act. (1990, 2008). Retrieved 2018 from www .eeoc.gov/eeoc/publications/fs-ada.cfm

Association of American Colleges and Universities. (2017). Making Excellence Inclusive. Retrieved 2018 from https://aacu.org/making-excellence -inclusive.

Brownwell, S., \& Tanner, K. (2012). Barriers to faculty pedagogical change: Lack of training, time, incentives, and ... tensions with professional identity? CBE-Life Sciences Education, 11, 339-346.

Byars-Winston, A. (2014). Toward a framework for multicultural STEM-focused career interventions. Career Development Quarterly, 62(4), 340-357.

Coalition for Reform of Undergraduate STEM Education. (2014). Achieving Systemic Change. A sourcebook for advancing and funding undergraduate STEM education. Washington, DC: Association of American Colleges and Universities.

Connolly, M. R., \& Millar, S. B. (2006). Using workshops to improve instruction in STEM courses. Metropolitan Universities, 17(4), 53-65.

Cox, M. D. (2004). Introduction to faculty learning communities. New Directions for Teaching and Learning, 97, 5-23.

Craig, R. (2015). Distance travelled: A new metric for colleges and universities Forbes. Retrieved 2018 from www.forbes.com/sites/ryancraig/2015/05/ 06/distance-traveled-a-new-metric-for-colleges-and-universities/2/ \#c7fc1893fa1f

Duckworth, A., Peterson, C., Matthews, M., \& Kelly, D. (2007). Grit: Perseverance and passion for long-term goals. Journal of Personality and Social Psychology, 92(6), 1087-1101.

Estrada, M., Burnett, M., Campbell, A. G., Campbell, P. B., Denetclaw, W. F., Gutiérrez, C. G., ... Zavala, M. (2016). Improving underrepresented minority student persistence in STEM. CBE-Life Sciences Education, 15(3), es5. doi: 10.1187/cbe.16-01-0038

Estrada, M., Eroy-Reveles, A., \& Matsui, J. (2018). The influence of affirming kindness and community on broadening participation in STEM career pathways. Social Issues and Policy Research, 12(1), 258-297.

Gibbs, K., Basson, J., Xierali, I., \& Broniatowski, D. A. (2016). Decoupling of the minority PhD talent pool and assistant professor hiring in medical school basic science departments in the US. eLife, 5, e21393.

Gibbs, K., \& Griffin, K. (2013). What do I want to be with my PhD? The roles of personal values and structural dynamics in shaping the career interests of recent biomedical science $\mathrm{PhD}$ graduates. CBE-Life Sciences Education, 12(4), 711-723.

Handelsman, J., Ebert-May, D., Beichner, R., Bruns, P., Chang, A., DeHaan, R., Tilghman, S. M. (2004). Scientific teaching. Science, 304(5670), 521-522.

Harackiewicz, J. M., Canning, E. A., Tibbetts, Y., Priniski, S. J., \& Hyde, J. S. (2016). Closing achievement gaps with a utility-value intervention: Disentangling race and social class. Journal of Personality and Social Psychology, 111(5), 745

Howard Hughes Medical Institute. (2017). Inclusive excellence. Retrieved 2018 from www.hhmi.org/sites/default/files/Programs/Inclusive/ Inclusive-Excellence-2018-Program-Announcement.pdf

Hurtado, S., Eagan, M. K., Tran, M., Newman, C., Chang, M., \& Velasco, P. (2011). "We do science here": Underrepresented students' interactions with faculty in different college contexts. Journal of Social Issues, 67(3), 553-579.

Jackson, M. C., Galvez, G., Landa, I., Buonora, P., \& Thoman, D. B. (2016). Science that matters: The importance of a cultural connection in underrepresented students' science pursuit. CBE-Life Sciences Education, 15(3), ar42

Kulkarni, S., \& Rothwell, J. (2015). Beyond college rankings: A value-added approach to assessing two- and four-year schools. Retrieved from www .brookings.edu/research/beyond-college-rankings-a-value-added -approach-to-assessing-two-and-four-year-schools.

Kwate, N., \& Meyer, I. (2010). The myth of meritocracy and African American health. American Journal of Public Health, 100(10), 1831-1834 
Lewis, M. (2004). Moneyball: The art of winning an unfair game (p. 317). New York: Norton.

Matsui, J., Liu, R., \& Kane, C. M. (2003). Evaluating a science diversity program at UC Berkeley: More questions than answers. Cell Biology Education, 2(2), 117-121.

McCoy, S. K., \& Major, B. (2007). Priming meritocracy and the psychological justification of inequality. Journal of Experimental Social Psychology 43(3), 341-351.

Minorities in Science-The Pipeline Problem. (1992). Science, 258, 1057-1276.

Nivet, M. A. (2011). Diversity 3.0: A necessary systems upgrade. Academic Medicine, 86(12), 1487-1489. doi: 10.1097/ACM.0b013e3182351f79

Schreiner, L. (2017). The privilege of grit. About Campus, 22(5), 11-20.
Seymour, E., \& Hewitt, N. (1997). Talking about Leaving: Why undergraduates leave the sciences (p. 429). Boulder, CO: Westview.

Thoman, D. B., Brown, E. R., Mason, A. Z., Harmsen, A. G., \& Smith, J. L. (2014). The role of altruistic values in motivating underrepresented $\mathrm{mi}$ nority students for biomedicine. BioScience, 65(2), 183-188.

Tinto, V. (2006). Research and practice of student retention: What next? Journal of College and Student Retention, 8(1), 1-19.

Valantine, H., \& Collins, F. (2015). National Institutes of Health addresses the science of diversity. Proceedings of the National Academy of Sciences USA, 112(40), 12240-12242.

Willingham, D. (2016). Ask the cognitive scientist: "Grit" is trendy, but can it be taught? American Educator, 40(2), 28-32. 